International Journal of Advanced Biotechnology Research.

ISSN 2249-3166 Volume 9, Number 1 (2019), pp. 13-24

(C) Research India Publications

https://dx.doi.org/10.37622/IJABR/9.1.2019.13-24

\title{
Organisation of Mycobacterium leprae mce operon and expression of mce genes in leprosy patients
}

\author{
Lini Nirmala ${ }^{1,2, *}$, Kuppamuthu Dharmalingam ${ }^{1,3}$ \\ ${ }^{1}$ Department of Genetic Engineering, School of Biotechnology, Madurai Kamaraj \\ University, Madurai-625 021, Tamil Nadu, India. \\ ${ }^{2}$ Department of Biotechnology, Mar Ivanios college, Thiruvananthapuram, India. \\ ${ }^{3}$ Aravind Medical Research Foundation, Madurai, India.
}

*Corresponding author: Lini Nirmala

\begin{abstract}
The pathogenesis of Mycobacterium leprae is largely due to its ability to enter and survive within human macrophages. Mammalian cell entry (mce) operons, implicated in the entry of mycobacteria into host cells, are important for the pathogenesis of M. leprae. Our earlier reports using RT-PCR demonstrated that mcel operon of M. leprae was expressed as a polycistronic mRNA. These studies were carried out using biopsy samples from lepromatous leprosy patients. To obtain an insight into the regulation of mcel operon of $M$. leprae across the leprosy spectrum, the expression of the mRNA of mcel genes were analysed by real-time PCR using biopsies from TT to LL cases. Results indicate that even though the mcel is organized as an operon, differential expression of the individual genes could be observed across the leprosy spectrum. Very low level of expression of mcelA was observed in all the samples across the spectrum, except in TT cases. In contrast, mce $1 C$ was up-regulated in BL and LL cases and mcelD was down regulated in polar lepromatous cases. Homology analysis using multiple alignments indicates highly conserved proline rich peptides in the $\mathrm{C}$ terminal region of Mce1C protein of pathogenic actinomycetes, however, these regions are absent in non-pathogenic species. This suggests that more than the presence or absence of the operon, the sequence specificity and differential expression may contribute to the virulence of the pathogen.
\end{abstract}




\section{INTRODUCTION}

In prokaryotes, functionally related genes are grouped into polycistronic operons that direct the synthesis of multiple translation products [23]. This organization facilitates the coordinated expression and regulation of functionally related genes, which enables bacteria to adapt quickly to the diverse conditions encountered during infection. Several operons were reported to be essential for the entry and survival of mycobacterium [10, 26] inside the host cell. Arruda et al [3] have reported one such operon from $M$. tuberculosis, which when expressed in E. coli, allows the recombinant bacteria to invade HeLa cells, whereas E. coli under normal conditions cannot invade HeLa cells. This operon was named as mammalian cell entry operon (mce). Analysis of complete genome of $M$. leprae indicated the presence of a single functional mcel locus and there were also pseudogenes for $m c e 1 A$ and $m c e 4 A$ located at distinct regions of the genome [9]. Subsequent analysis showed the presence of this operon in other mycobacteria as well as in many other actinomycetes [6, 13]. The organization of mce operon was similar in all the cases examined so far. In each case, mce locus is preceded by genes $y r b E 1 A$ and $y r b E 1 B$, encoding two integral membrane proteins. The predicted start codon of each of the six mce gene (mcelA to mcelF) products either overlaps with the upstream gene or is preceded by a gap, suggesting that their expression is coupled both transcriptionally and translationally.

Understanding the organization of operons in a bacterial genome provides insights into both gene function and regulation. Reports of mce operon in M. leprae are limited $[29,36]$ and there were no reports showing the role of mcel operon in virulence and pathogenesis of $M$. leprae. Earlier studies from our laboratory showed that mce operon was expressed as a polycistronic mRNA in lepromatous biopsy samples and the mcel operon of M. leprae was expressed in M. Smegmatis [29]. In this study we have analysed the expression of mcel operon across the leprosy spectrum, in order to examine the regulation of expression of mcel genes.

\section{MATERIALS AND METHODS}

\section{Patients and samples}

Leprosy patients were classified according to Ridley and Jopling [27]. Patients were selected after careful medical examination. Punch biopsies from patients were collected after obtaining the informed consent, as per the norms laid down by the institutional ethical committee and Indian Council of Medical Research. This study includes thirty patients across the leprosy spectrum: tuberculoid or TT $(n=5)$, borderline tuberculoid or BT $(\mathrm{n}=5)$, borderline lepromatous or BL $(\mathrm{n}=5)$, lepromatous leprosy or LL $(n=5)$, type I reaction or RR $(n=5)$ and type II reaction or ENL $(n=5)$. The bacterial load in each biopsy sample was determined by acid fast staining and expressed on a logarithmic scale as Bacterial Index.

\section{Extraction of RNA and preparation of cDNA}

Total RNA from FFPE tissue biopsies was extracted as described earlier [30]. In brief, sections were deparaffinated in xylene and samples were incubated in digestion buffer 
(10 mM Tris $\mathrm{HCl}, 25 \mathrm{mM}$ EDTA, $100 \mathrm{mM} \mathrm{NaCl}, 0.5 \%$ SDS, Proteinase $\mathrm{K}$ at a final concentration of $300 \mu \mathrm{g} / \mathrm{mL}$ ), for $24 \mathrm{hrs}$ at $52{ }^{\circ} \mathrm{C}$ followed by Trizol extraction. Concentration of RNA was determined using a Spectrophotometer. RNA was treated with DNAse as per manufacturer's instruction (Promega, Madison, USA). Total RNA $(3 \mu \mathrm{g})$ was reverse transcribed in a final volume of $50 \mu \mathrm{L}$ using conventional programmable thermal cycler (M.J. Research Inc, USA). The reaction mix containing RNA, $1 \mu \mathrm{g}$ oligo $\mathrm{dT}_{15}$ and $1 \mu \mathrm{g}$ random hexamers (Promega, Madison, USA) were incubated at $70{ }^{\circ} \mathrm{C}$ for $10 \mathrm{~min}$ and chilled on ice. Master mix containing $10 \mu \mathrm{L}$ MML$\mathrm{V}$ reaction buffer $(5 \mathrm{X}), 2.5 \mu \mathrm{L}$ dNTP mix (10 mM each), $2 \mu \mathrm{L}$ ribonuclease inhibitor $(20 \mathrm{U} / \mu \mathrm{L}), 200 \mathrm{U}$ MML-V reverse transcriptase (Amersham Pharmacia Biotech, USA.) were added and incubated at $37{ }^{\circ} \mathrm{C}$ for one hour. The enzyme was heatinactivated at $92{ }^{\circ} \mathrm{C}$ for $2 \mathrm{~min}$ and cDNA was stored at $-20{ }^{\circ} \mathrm{C}$. Assay without MML$\mathrm{V}$ reverse transcriptase was included as a negative control for each sample analyzed (RT-minus control).

\section{Conventional PCR}

PCR amplification of the template DNA and RNA was carried out using thermal cycler PTC 200 (M.J.Research, Inc, USA.). Cycling parameters were: Initial denaturation at $94{ }^{\circ} \mathrm{C}$ for three min, denaturation at $94{ }^{\circ} \mathrm{C}$ for one min, annealing at 55 ${ }^{\circ} \mathrm{C}$ for one min, extension at $72{ }^{\circ} \mathrm{C}$ for one min for 36 cycles followed by a final extension for seven min. PCR was performed in a $25 \mu \mathrm{L}$ reaction mix containing $5 \mu \mathrm{L}$ of cDNA, 1.25 units of Taq Polymerase (Fermentas Int. Inc, USA), $2 \mu \mathrm{L}$ of $\mathrm{MgCl}_{2}$ (final concentration $1 \mathrm{mM}$ ) and $2 \mu \mathrm{L}$ of dNTPs (final concentration $100 \mathrm{nM}$ ). PCR products were separated in an agarose gel and visualized by ethidium bromide staining.

\section{Real-time PCR analysis}

Real-time PCR analysis was performed using SYBR Green chemistry in ABI prism 7000-sequence detection system (PE Applied Biosystem, Foster City, USA). All the primers were designed using Primer Express Software (PE Applied Biosystem, Foster City, USA) and the primers were purchased from Microsynth (Microsynth, Balgach, Switzerland). Oligonucleotide sequences of the primers used for real-time PCR assays were shown in Table.1. Two-step SYBR Green assays were performed in a reaction volume of $25 \mu \mathrm{L}$ using SYBR Green master mix (Euro genetic, Germany). Primer concentrations were optimized using $50 \mathrm{nM}$ to $900 \mathrm{nM}$ and the optimum concentration was used in all experiments. Real-time PCR analysis was performed using the following optimum assay conditions; $10 \mathrm{~min}$ at $94{ }^{\circ} \mathrm{C}$ followed by $15 \mathrm{sec}$ at $94{ }^{\circ} \mathrm{C}$ and one min at $60{ }^{\circ} \mathrm{C}$ of 40 cycles. Amplifications were performed in duplicate or in triplicate wells. For each samples analyzed RT-minus controls and non-template controls were included. Melting curve analysis (Applied Biosystem software) was performed after each run to confirm the specificity of the primers used. 
Expression profiling of mce operon across the leprosy spectrum was performed by relative quantification method [24]. Five samples were collected from each spectrum of leprosy. Each sample was analyzed in duplicates or in triplicates using the primers specified in Table. 1. Ct values in each sample were averaged and $\Delta \mathrm{Ct}$ values were calculated by using 16SrRNA as endogenous control. In order to compare the expression of mce operon genes in each case of leprosy, mcelA was used as calibrator, which showed lowest expression compared to other genes in the cluster. Fold change expression was calculated by using the formula $2^{-\Delta \Delta \mathrm{Ct}}$. Standard deviation in each case was also calculated.

Table.1. Details of the real- time PCR primers used in the analysis of the mce operon of M. leprae.

\begin{tabular}{|l|l|l|l|}
\hline Primer sequence-5' ${ }^{\prime}{ }^{\prime}$ & Gene & $\begin{array}{l}\text { Length } \\
\text { primer }\end{array}$ & $\begin{array}{l}\text { Amplicon } \\
\text { (bp) }\end{array}$ \\
\hline RM1aF:ACGGTCTTCGGCGGTAAGTA & $m c e 1 A$ & $20 \mathrm{bp}$ & $143 \mathrm{bp}$ \\
RM1aR:TCCGCGATCAAGGTTATGGT & & $20 \mathrm{bp}$ & \\
\hline $\begin{array}{l}\text { RM1bF:ACGACATCCTCGACCAAACC } \\
\text { RM1bR:GTTGACGGTCTGGTCGAATTC }\end{array}$ & $m c e 1 B$ & $\begin{array}{l}20 \mathrm{bp} \\
21 \mathrm{bp}\end{array}$ & $140 \mathrm{bp}$ \\
\hline $\begin{array}{l}\text { RM1cF:GCACAAGTGGACCGATTGTTG } \\
\text { RM1cR:TTGAGGTTCGGGTTGTCGTT }\end{array}$ & $m c e 1 C$ & $\begin{array}{l}21 \mathrm{bp} \\
20 \mathrm{bp}\end{array}$ & $146 \mathrm{bp}$ \\
\hline $\begin{array}{l}\text { RM1dF:TCAGCAGTTTGTTGCCTTGAA } \\
\text { RM1dR:GTACCTCGCGGTTCTTAACGA }\end{array}$ & $m c e 1 D$ & $\begin{array}{l}21 \mathrm{bp} \\
21 \mathrm{bp}\end{array}$ & $146 \mathrm{bp}$ \\
\hline $\begin{array}{l}\text { RM1eF:CAGGCCGTCGATCAGTACTTG } \\
\text { RM1eR:TACGGCTGGGTCAGGATCA }\end{array}$ & $m c e 1 E$ & $\begin{array}{l}21 \mathrm{bp} \\
19 \mathrm{bp}\end{array}$ & $140 \mathrm{bp}$ \\
\hline $\begin{array}{l}\text { RM1fF:CGTTGCCGAAGGAAAAGATC } \\
\text { RM1fR:TCGTTGACGTCGGTGATGTT }\end{array}$ & $m c e 1 F$ & $\begin{array}{l}20 \mathrm{bp} \\
20 \mathrm{bp}\end{array}$ & $142 \mathrm{bp}$ \\
\hline $\begin{array}{l}\text { R16SF:CGAGCGTTGTCCGGAATT } \\
\text { R16SR:TCCACCGCTACACCAGGAA }\end{array}$ & $16 S r R N A$ & $\begin{array}{l}18 \mathrm{bp} \\
19 \mathrm{bp}\end{array}$ & $151 \mathrm{bp}$ \\
\hline
\end{tabular}

\section{RESULTS}

\section{Organization and expression of mce operon in leprosy cases}

RNA was extracted from paraffin embedded biopsies as described under materials and methods. Our earlier reports showed that mce locus was organized as an operon in $M$. leprae and the messengers were co-expressed in infected human tissue [29]. Gene specific primers were used for amplifying the mRNA corresponding to each gene of mcel operon. Real-time PCR analyses were performed to calculate the relative expression of the transcripts across the leprosy spectrum. 


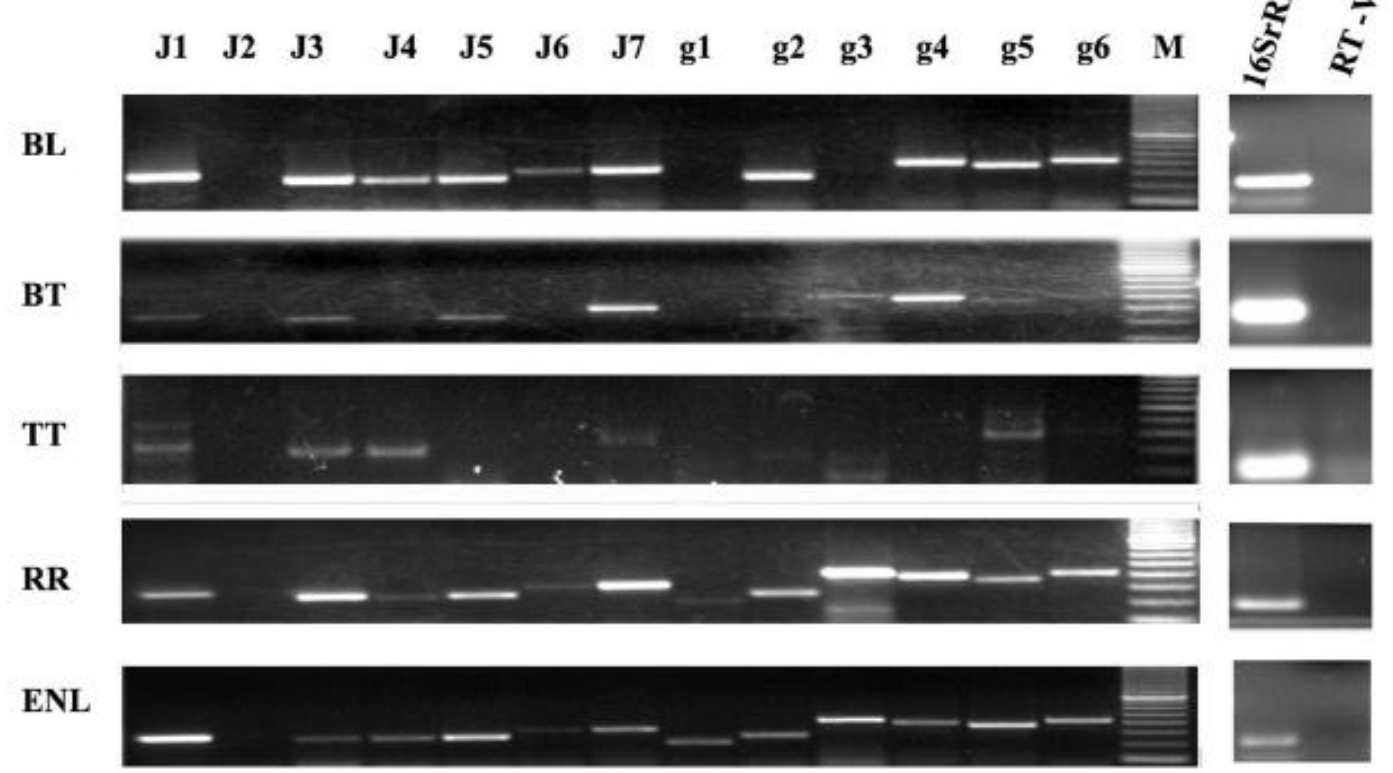

Fig. 1. Organization of mce operon of M. leprae in leprosy biopsy samples. RTPCR analysis was carried out, using mRNA of leprosy patients across the spectrum, as described earlier (Santhosh et al., 2005). Representative samples from each leprosy cases were shown. Lanes are marked with names of the primer sets used for amplification. $\mathrm{J} 1$ to $\mathrm{J} 7$ represent intergenic primers and g1 to g6 represent internal primers of mce operon, $\mathrm{M}$ - Molecular weight marker.

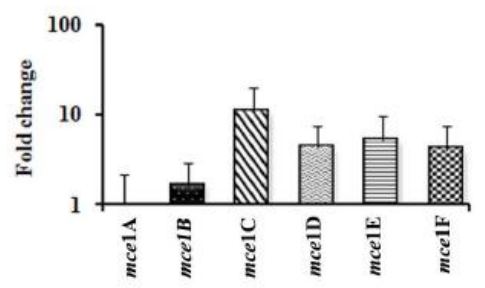

Fig.2.a

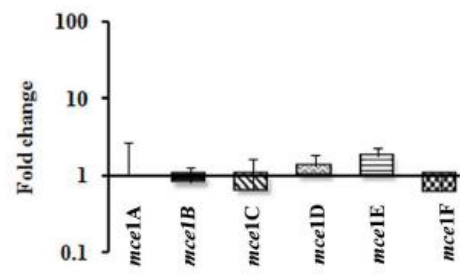

Fig.2.d

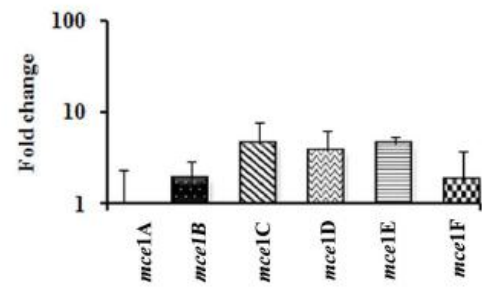

Fig.2.b

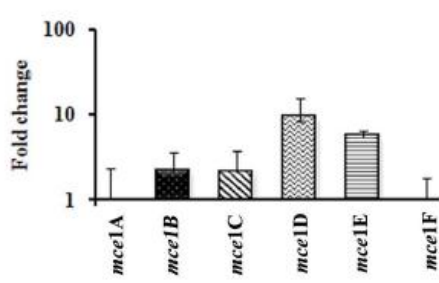

Fig.2.C

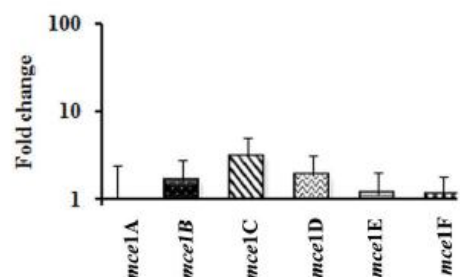

Fig.2.e

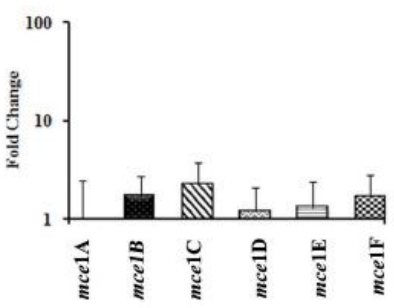

Fig.2.f

Fig. 2. Expression profiling of mce operon in leprosy cases using real-time PCR. 
Relative expression level of mce operon in each case of leprosy was quantified using mcelA as calibrator sample. Details are described under materials and methods. Fig.2.a-LL, Fig.2b- BL, Fig.2.c-BT, Fig.2.d-TT, Fig.2.e-RR, Fig.2.f- ENL. Error bars represent standard deviation.

\begin{tabular}{|c|c|c|}
\hline N.tarcina & 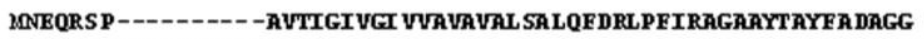 & 50 \\
\hline $\begin{array}{l}\text { S.coelicolar } \\
\text { M. Ieprae }\end{array}$ & $\begin{array}{l}\text { IOKRPRG KPLFKPVKER NP VAVGVAGL L VLTL VALLVYNVDRLPFG-GGTTYSADF S ESAG } \\
\text { IRTTLE P-- }\end{array}$ & $\begin{array}{l}59 \\
51\end{array}$ \\
\hline \multirow[t]{2}{*}{ M. tuberculosis } & 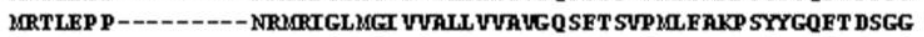 & 51 \\
\hline & $\ldots \quad: *: \quad . \quad: *{ }^{*} *::: *$ & \\
\hline N.Earcina & LVPGDN VQVAGUR SGR VDEVELAGDK VL VRFTLDES IVLGDKT SARIKTNTVLGRK SLEV & 110 \\
\hline S. coelicolar & LDEGDE VRT FGVKUGQ VTGVALDGAKVXVSFEVED- AWIGDRTTARTATKTVLGDKYLAL & 118 \\
\hline M. Ieprae & LNKGDK VRI FGLDUGK VEALKIDGDHVVIKF SIGT-NRIGTASRLGIRTDTVLGKK VLEV & 110 \\
\hline \multirow[t]{2}{*}{ M. taberculosis } & LHKGDR VRI AGLGUGT VEGLKIDGDHIVVKF SIGT-NTIGTE SRLATRTDTILGRK VLEI & 110 \\
\hline & 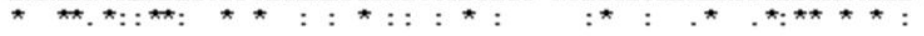 & \\
\hline N.Earcina & VPAGAGALRPADTIPL ERTTSPYSLNDALGELATTVDGLDADVDQTLDALSATFA DTPĂ & 170 \\
\hline S. coelicolar & DPLGSGRQDPGARIPL ARTTSPYDVT QFFQDLSGTVDDIDTGRLAESFETISDTFKDSPP & 178 \\
\hline M. Ieprae & ETRGTQLLRPGDSLPLGOSTTPYQSY DFFFDATKVA SGWNDTIKQSLKVUSETIDQTYP & 170 \\
\hline \multirow[t]{2}{*}{ M. taberculosis } & EPRGAQALPPGGULPUGOSTTPYQTY DAFFDUTKAA SGWIETUKRSLNULSETVDQTYP & 170 \\
\hline & 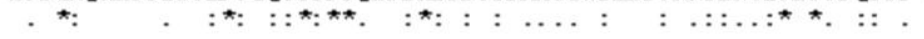 & \\
\hline N.Earcina & PLRAAL DGVTEL SRTI NSRDOAL SQL LERFONUTKI L SDRSAQINALLLDGNQLLGELDA & 230 \\
\hline S. $\infty$ elicolar & FURKAA TGL SDL SKSI SKRDAKL SEL LKGSARFTKT LENNKS SFETLIEDGGPLLGELRD & 238 \\
\hline M. Teprae & HL SAAL DGVAKF SDTI GARDKEIKHL IAQANQVASVLGDRGAOVDRLL VNTKTLIAAFNE & 230 \\
\hline \multirow[t]{2}{*}{ M. taberculosis } & KL SFAL DGVAKF SDTI GKRDEOITHL LAQANQVASI LGDRSEQVDRLL VNAKTLIAAFNE & 230 \\
\hline & 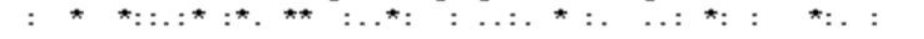 & \\
\hline N.tarcina & RRTAIGQLIVNUNGARQQLFGL VADNEAOLOPALDRLNSVLDVLRNRQNTTEALDGGP & 290 \\
\hline S. coelicolar & RRTAINALLKGSQDLGTELGGL VKDNEKQLGPTLKALGRVTSVLEKNNTRLGETLALVGP & 298 \\
\hline M. leprae & RGRAVD ALLGNVAAFA AQVORLINDN - PNLNFVLLQ LHQL SGIL VOHKDDLANTLI QVAA & 289 \\
\hline \multirow[t]{2}{*}{ M. taberculosis } & RGRAVD ALLGNI SAF S AOVONLINDN - PNLNFVLDQLRILTDLLVDRKEDLAETLT IIGR & 289 \\
\hline & 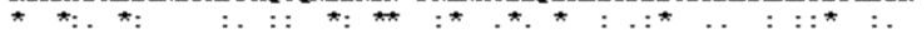 & \\
\hline N.tarcina & FAARLGEQVGNGPUFN AYYUNAT SUGLQPLWDAL WVP----------------E HLPA & 332 \\
\hline S.coelicolar & YYRLVGNTLGNGRUED SYLOGVUPR- & 328 \\
\hline M. Teprae & FLPSLNEAIGSGPFFKVULHNLAPYQILQPWNDAFF KKRGDPENFURSAGLPEFRFPDP & 349 \\
\hline \multirow[t]{2}{*}{ M. taberculosis } & FSASFGETFASGPYFK ULLANL VPQOILQPF VDAFF KKRGISPEDFURSAGLPAYRVPDP & 349 \\
\hline & $: \quad \ldots: \ldots:^{*} . \quad: \ldots$ & \\
\hline N.farcina & 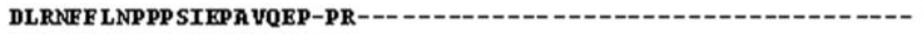 & 354 \\
\hline S.coelicolar & TSOPST GCLPPKOPAAAOGSGAR- & 351 \\
\hline \multirow{3}{*}{$\begin{array}{l}\text { M. Ieprae } \\
\text { M. taberculosis }\end{array}$} & NGTEFP NGAPPPAPPVLEGTPENPGP AVPPGSPCSYT THFPGNNTIGDELGLPRPWNPL & 409 \\
\hline & NGTEFP NGAPPPPPPVLEGTPEHPGP AVPPGSPCSYT TPADG--------LPRPVDPL & 399 \\
\hline & & \\
\hline $\begin{array}{l}\text { N. Earcina } \\
\text { S.coelicolar }\end{array}$ & 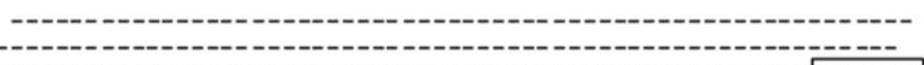 & \\
\hline $\begin{array}{l}\text { M. Teprae } \\
\text { M.taberculosis }\end{array}$ & $\begin{array}{l}\text { PCAGAT AGPYGGP FFP APIDUOT SPP NPDG PLLPGIAIAGRPGDPAPNUPGT VP LPPN } \\
\text { PCANLT QGPFGGPDFP APLDUAT SPP NPDGPPAPGLPIAGRPGEVPPNUGT UP IPQE }\end{array}$ & 469 \\
\hline N. & & \\
\hline S.coelioo & & \\
\hline $\begin{array}{l}\text { M. Teprae } \\
\text { M.taberculosis }\end{array}$ & 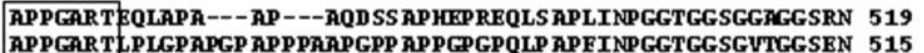 & \\
\hline M. tuberculosis & APPGARTAPLGPAPGP APP PARPGPP APPGPGPQLP APFINPGGTGGSGVTGGSEN 515 & \\
\hline
\end{tabular}

Fig.3. Multiple sequence alignment of the Mce1C sequences from four actinomycetales using ClustalW programme

Nocardia farcinica (Accession number YP 116748.1), Streptomyces coelicolor (Accession number NP 626662.1), Mycobacterium tuberculosis (Accession number NP 214685.1), Mycobacterium leprae (Accession number NP 302658.1). The conserved proline rich regions in M. tuberculosis and M. leprae are marked in boxes. 
Results indicate that the mcelC and the mcelE mRNA showed higher level of expression in lepromatous leprosy cases when compared to other genes in the cluster (Fig. 2a). Inter-genic transcripts could be detected in LL as well as BL cases, except the inter-genic region spanning $y r b E 1 B /$ mcelA (Fig.1a) loci. In contrast to the LL case, mce $1 C$ and mcelE transcripts showed similar level of expression in BL (Fig. 2b) when compared to other genes. The level of expression of mcelD (3.73 fold) was significantly high in BL cases. However, in BT cases, most of the gene transcripts were down regulated. Inter-genic transcripts of $m c e 1 B / C$ and $m c e 1 D / E$ could not be detected in $80 \%$ of the BT samples analyzed (Fig. 1b.) Real-time PCR analysis showed that, mcelD mRNA expression was higher than that of other genes in the cluster including in the BT(Fig. 2c). This increase in mce $1 D$ mRNA, when compared to $\mathrm{LL}$ and BL cases, indicates a selective up regulation of mce $1 D$ mRNA in BT cases. The significance of this increased expression at such an early stage of leprosy has not been shown earlier. The expression of mcelC mRNA was lower than that of mcelB and $m c e l E$, which suggests either the occurrence of differential processing of mRNA of each of these genes or the presence of additional promoters with different strength. A prominent baseline expression of mce $1 F$ mRNA could be detected in BT cases. At the tuberculoid end of the spectrum, amplicons corresponding to the intergenic regions of $m c e l C / m c e 1 D$, mce $1 D / m c e l E$ and mcelE/ mcelF could not be detected in all the samples analyzed (Fig.1c). However, real-time PCR analysis shows a significant higher level of expression of mcelE and mcelD mRNA (Fig.2.d). Interestingly, the expression levels of mce $1 B$, mce $1 C$ and mce $1 F$ mRNA were lower than that of mcelA mRNA in tuberculoid cases.

\section{Organization and expression of mce operon in reactions}

A number of patients undergo intermittent, acute, immunologically mediated inflammatory events called reactions. Borderline leprosy patients often undergo acute changes in immune reactivity that manifest as reversal reaction (RR) during the course of the disease $[12,20]$. $\mathrm{RR}$ is associated with an exacerbated local delayed-type cellular immune response to $M$. leprae and is responsible for severe tissue damage. Some of the BL and LL patients develop a type 2 reaction called ENL, a painful, immune mediated inflammatory condition, which is thought to arise from deposition of immune complexes in target organs and skin [25]. RT-PCR analysis could detect the presence of intergenic transcripts in all the samples except for the region of $y \mathrm{rbE1B/mce1A}$ in RR (Fig.1d) and ENL cases (Fig.1e). Higher level of expression of mce $1 C$ mRNA (2.99 fold) could be detected in RR cases (Fig.2e). At the same time, mce $1 B$ (1.62) and mcelD (1.84) showed similar level of expression. However, mcelE expression was lesser than that of mcelC. mcelF showed only base line expression. In contrast to RR, ENL, showed higher level of expression of mcelF (1.66 fold) which was higher than that of mcelD (1.2) and mcelE (1.3) (Fig.2f). 


\section{Homology analysis of the Mce proteins of pathogenic and nonpathogenic actinomycetales.}

An earlier report indicated that mce operon was present in a wide variety of actinomycetales and was predicted to act as ABC importers [6]. However, in pathogenic mycobacteria, the product of this operon was reported to help in the virulence and pathogenesis of the bacilli [11,32,]. In order to examine the role of this operon in pathogenesis, Mce operon of four bacterial species were compared; $M$. tuberculosis and M. leprae which are human pathogens, $N$. farcinica, a gram positive, partially acid fast, filamentous bacillus, which is an opportunistic pathogen and $S$. coelicolar, a nonpathogenic saprophytic actinomycete. Results indicate that Cterminal region is highly variable compared to the $\mathrm{N}$ terminal region (data not shown). Interestingly, highly conserved proline rich regions could be observed in the $\mathrm{C}$ terminal end of Mce1C protein of pathogenic bacteria. However, this region was absent in nonpathogenic actinomycetales (Fig.3.). Several proline rich peptides, which are interacting with SH3 binding domains, were reported earlier. These peptide SH3 ligands were identified in phage display libraries [22, 33]. This indicates that this region may have an important role in the virulence of the pathogen.

\section{DISCUSSION}

Surface exposed membrane components of bacteria have a role in the virulence and pathogenesis, as these are the earliest proteins to interact with the host cell $[5,35]$. Proteins encoded by the mammalian cell entry operon of mycobacteria is localized on the cell membrane of $M$. tuberculosis [32, 31] and helps in the adherence and internalization of bacteria [19, Rodriguez et al. 2015 ]. Our earlier experiments demonstrated that mce operon was expressed as a polycistronic mRNA in LL patients and in Armadillo derived M. leprae [29]. This study was carried out to analyse the expression pattern of the constituent genes of mce operon across the leprosy spectrum. RT-PCR analysis indicates significant quantitative changes in the level of transcripts carrying the intergenic segments. This observation suggests a differential regulation of the genes of the mce operon across the leprosy spectrum. Analysis of mce operon using real-time PCR shows the presence of mcel transcripts across the leprosy spectrum. mcelC transcript was up regulated as the spectrum moves towards the polar lepromatous condition. Comparison of the mce operon indicates that, highly conserved proline rich regions are present in the $\mathrm{C}$ - terminal region of Mce1C protein of pathogenic species. Many surface proteins in pathogenic bacteria are shown to have proline rich peptide regions, exposed to bacterial surface. In these cases the proline rich region is located in the $\mathrm{C}$ terminal, wall proximal half of the protein, which helps the protein to interact with the host protein and other surface proteins [2]. Reports show that the $\mathrm{C}$ terminal regions of proteins contribute to virulence of the pathogen [8]. Proline rich peptides play an important role in many protein-protein interactions, such as signalling events involving SH3 domains in eukaryotes $[17,37]$. Highest level of expression of mcelC in lepromatous leprosy cases and the presence of proline rich regions imply that mcelC may be an active virulent gene in mce 
person, which would facilitate the establishment of infection. Phosphorylation is a common mechanism for the regulation of protein function. These proline rich sites of the pathogen are likely to form substrates of host kinases, thereby mimicking the host signalling pathway and subverting the metabolism, in order to alter the very process of pathogenesis. However, further experiments are needed to prove this point.

Significant higher level of expression of $m c e 1 A$ and $m c e l E$ in TT cases indicates that $m c e 1 A$ and $m c e 1 E$ could be the genes expressed early to help in the entry and survival of the bacteria. Several lipoproteins in pathogenic bacteria are reported to be essential for the virulence of the pathogen, since they could modulate the host immune response by activating Toll like receptors $[4,34]$ and are known to induce cytokine production in macrophages [15]. The abundance of mcelE - the lipoprotein component of the mce operon-implies that this gene could be involved in the modulation of immune response to $M$. leprae infection.

Interestingly, as reported earlier, no transcript could be detected in the intergenic region between $y \mathrm{rbE1B/mcelA}$ in any of the cases analyzed [29]. This shows the probability of a promoter region of mce operon in $y r B E 1 B$ gene. In contrast, $M$. tuberculosis mce was organized as 13 gene polycistronic mRNA, and the intergenic transcript that corresponds to $y \mathrm{rbE} 1 \mathrm{~B} /$ mce $1 \mathrm{~A}$ was detected in these cases. The operon organization includes the upstream genes fadD5 and mcelR. mcelR is a transcriptional repressor of mce operon, which regulates mce operon expression [7]. However, mcelR is absent in M. leprae genome (data not shown). This shows that, even if the organization of mcel operon is similar in M. tuberculosis and M. leprae, their mechanisms of regulation may be different in these two pathogens, indicating a different mechanism for establishment of infection in the early stages. There are several reports, which demonstrate the differential expression of polycistronic operon, especially in the $\mathrm{ABC}$ transporter family of proteins $[1,14,16,18,21]$. YrbE1 protein and Mce protein show homology to ATP binding cassette (ABC) transporter permease and Substrate binding protein, respectively [6], and has been implicated in the import of glutamate and phosphatidic acid as substrates. These results along with our data imply that, differential mRNA decay may provide a mechanism for controlling the relative amounts of protein components in mce operon. This may help to facilitate the regulation of the uptake of factors required for the survival of pathogen under adverse host conditions as well as to establish a persistent state of infection.

\section{ACKNOWLEDGEMENTS}

KD thanks the Department of Biotechnology, New Delhi, India, for grants DBT/TIO7/35/SWS/Dharma/95, CGESM: BT/03/002/87volVI and Indian Council of Medical Research for grant 63/21/002-BMS. NL thanks University Grant Commission for the award of Senior Research Fellowship, New Delhi, India. 


\section{REFERENCES}

1. Allenby, NE., O'Connor N., Pragai Z et al (2004) Post-transcriptional regulation of the Bacillus subtilis pst operon encoding a phosphate-specific ABC transporter. Microbiology 150:2619-2628

2. Areschoug T, Linse S, Stalhammar-Carlemalm M et al (2002) A proline-rich region with a highly periodic sequence in streptococcal $\{$ beta $\}$ protein adopts the polyproline II structure and is exposed on the bacterial surface. Journal of Bacteriology 184:6376-6383

3. Arruda S, Bomfim G, Knights R et al (1993) Cloning of an M. tuberculosis DNA fragment associated with entry and survival inside cells. Science 261:1454-1457

4. Bas S, Neff L, Vuillet M et al (2008) The Proinflammatory Cytokine Response to Chlamydia trachomatis Elementary Bodies in Human Macrophages Is Partly Mediated by a Lipoprotein, the Macrophage Infectivity Potentiator, through TLR2/TLR1/TLR6 and CD14. J Immunol 180:1158-1168

5. Brightbill HD, Libraty DH, Krutzik SR et al (1999) Host defense mechanisms triggered by microbial lipoproteins through toll-like receptors. Science 285:732736

6. Casali N , Riley LW (2007) A phylogenomic analysis of the Actinomycetales mce operons. BMC Genomics 8:60

7. Casali N, White AM , Riley LW (2006) Regulation of the Mycobacterium tuberculosis mce1 operon. J Bacteriol 188:441-449

8. Champion PADG, Stanley SA, Champion MM et al (2006) C-terminal signal sequence promotes virulence factor secretion in Mycobacterium tuberculosis. Science 313:1632-1636

9. Cole ST, Eiglmeier K, Parkhill J et al (2001) Massive gene decay in the leprosy bacillus. Nature 409:1007-1011

10. Festa RA, Pearce MJ , Darwin KH (2007) Characterization of the proteasome accessory factor (paf) operon in Mycobacterium tuberculosis. J Bacteriol 189:3044-3050

11. Gioffre A, Infante E, Aguilar D et al (2005) Mutation in mce operons attenuates Mycobacterium tuberculosis virulence. Microbes Infect 7:325-334

12. Godal T, Myrvang B, Samuel DR et al (1973) Mechanism of "reactions" in borderline tuberculoid (BT) leprosy. A preliminary report. Acta Pathol Microbiol Scand Suppl 236:45-53

13. Haile Y, Caugant DA, Bjune G et al (2002) Mycobacterium tuberculosis mammalian cell entry operon (mce) homologs in Mycobacterium other than tuberculosis (MOTT). FEMS Immunol Med Microbiol 33:125-132

14. Hardham JM, Stamm LV, Porcella SF et al (1997) Identification and 
transcriptional analysis of a Treponema pallidum operon encoding a putative $\mathrm{ABC}$ transport system, an iron-activated repressor protein homolog, and a glycolytic pathway enzyme homolog. Gene 197:47-64

15. Henderson B, Poole S ,Wilson M (1996) Bacterial modulins: a novel class of virulence factors which cause host tissue pathology by inducing cytokine synthesis. Microbiol Rev 60:316-341

16. Homuth G, Mogk A , Schumann W (1999) Post-transcriptional regulation of the Bacillus subtilis dnaK operon. Mol Microbiol 32:1183-1197

17. Kay BK, Williamson MP, Sudol M (2000) The importance of being proline: the interaction of proline-rich motifs in signaling proteins with their cognate domains. The FASEB Journal 14:231-241

18. Khun HH, Deved V, Wong H, Lee BC (2000) fbpABC gene cluster in Neisseria meningitidis is transcribed as an operon. Infect Immun 68:7166-7171

19. Kohwiwattanagun J, Kawamura I, Fujimura T et al (2007) Mycobacterial mammalian cell entry protein $1 \mathrm{~A}$ (Mce1A)-mediated adherence enhances the chemokine production by A549 alveolar epithelial cells. Microbiol Immunol $51: 253-261$

20. Kumar B, Dogra S, Kaur I (2004) Epidemiological characteristics of leprosy reactions: 15 years experience from north India. Int J Lepr Other Mycobact Dis $72: 125-133$

21. Newbury SF, Smith NH, Robinson EC et al (1987). Stabilization of translationally active mRNA by prokaryotic REP sequences. Cell 48:297-310

22. Niebuhr K, Ebel F, Frank R et al (1997) A novel proline-rich motif present in ActA of Listeria monocytogenes and cytoskeletal proteins is the ligand for the EVH1 domain, a protein module present in the Ena/VASP family. EMBO J $16: 5433-5444$

23. Overbeek R, Fonstein M, D'Souza M et al (1999) The use of gene clusters to infer functional coupling. Proc Natl Acad Sci U S A 96:2896-2901

24. Overbergh L, Giulietti A, Valckx D et al (2003) The use of real-time reverse transcriptase PCR for the quantification of cytokine gene expression. J Biomol Tech 14:33-43

25. Pocaterra L, Jain S, Reddy R et al (2006) Clinical course of erythema nodosum leprosum: an 11-year cohort study in Hyderabad, India. Am J Trop Med Hyg 74:868-879

26. Ramaswamy SV, Amin AG, Goksel S et al (2000) Molecular genetic analysis of nucleotide polymorphisms associated with ethambutol resistance in human isolates of Mycobacterium tuberculosis. Antimicrob Agents Chemother 44:326336

27. Ridley DS, Jopling WH (1966) Classification of leprosy according to immunity. 
A five-group system. Int J Lepr Other Mycobact Dis 34:255-273

28. Rodriguez DC, Ocampo M, Varela Y, Curtidor H, Patarroyo MA, Patarroyo ME (2015) Mce4F Mycobacterium tuberculosis protein peptides can inhibit invasion of human cell lines. Pathog Dis. 73:pii: ftu020

29. Santhosh RS, Pandian SK, Lini N et al (2005). Cloning of mce1 locus of Mycobacterium leprae in Mycobacterium smegmatis mc2 155 SMR5 and evaluation of expression of mcel genes in M. smegmatis and M. leprae. FEMS Immunol Med Microbiol 45:291-302

30. Shabaana AK, Venkatasubramani R, Narayan NS et al (2001) Cytokine profiles in paraffin-embedded biopsy samples of lepromatous leprosy patients: semiquantitative measure of cytokine mRNA using RT-PCR. Int J Lepr Other Mycobact Dis 69:204-214

31. Singh P, Katoch VM, Mohanty KK, Chauhan DS (2016) Analysis of expression profile of mce operon genes (mce1, mce2, mce3 operon) in different Mycobacterium tuberculosis isolates at different growth phases Indian J Med Res. 143(4):487-94.

32. Shimono N, Morici L, Casali N et al (2003) Hypervirulent mutant of Mycobacterium tuberculosis resulting from disruption of the mce1 operon. Proc Natl Acad Sci U S A 100:15918-15923

33. Sparks AB, Hoffman NG, McConnell SJ et al (1996) Cloning of ligand targets: systematic isolation of SH3 domain-containing proteins. Nat Biotechnol 14:741744

34. Takeuchi O, Kawai T, Muhlradt PF et al (2001) Discrimination of bacterial lipoproteins by Toll-like receptor 6. Int Immunol 13:933-940

35. Underhill DM, Ozinsky A, Hajjar AM et al (1999) The Toll-like receptor 2 is recruited to macrophage phagosomes and discriminates between pathogens. Nature 401:811-815

36. Wiker HG, Spierings E, Kolkman MA et al (1999) The mammalian cell entry operon 1 (mce1) of mycobacterium leprae and mycobacterium tuberculosis. Microb Pathog 27:173-177

37. Williamson MP (1994) The structure and function of proline-rich regions in proteins. Biochemical Journal 297: 249-260 